\title{
ASSESSMENT OF PROTECTIVE ROLE OF GREEN TEA EXTRACT (GTE) AND N-ACETYLCYSTEINE (NAC) AGAINST THE POTENTIAL GENOTOXICITY OF NICOTINE IN ADULT MALE ALBINO RATS
}

\author{
Asmaa S. El-Banna a , Fatma Mohamed Magdy Badr El Dine ${ }^{\text {b }}$, Riham Abd El \\ Halim $^{\mathrm{c}}$ \\ ${ }^{a}$ Associate Professor of Forensic Medicine \& Clinical Toxicology, Alexandria University, \\ Egypt \\ ${ }^{\mathrm{b}}$ Associate Professor of Forensic Medicine \& Clinical Toxicology, Alexandria University, \\ Egypt \\ ${ }^{\mathrm{c}}$ Lecturer of Clinical Pathology, Alexandria University, Egypt \\ Corresponding author: Asmaa Said El-Banna
}

Department of Forensic Medicine\& Clinical Toxicology, Faculty of Medicine, Alexandria University, Egypt E-mail address: elbanna.asmaa@yahoo.com

\begin{abstract}
Introduction: nicotine itself is not classified as a carcinogen, but there is growing evidence that it may have genotoxic potential which has been a point of research interest. Objectives: The present study was designed specifically to investigate the possible genotoxic effect of nicotine in adult male albino rats and to assess the probable protective role of green tea (GTE) and N-acetyl cysteine (NAC). Material and methods: The study was carried out for four weeks on 30 adult male albino rats that were randomly divided into 6 equal groups. Group I: Rats received $3 \mathrm{ml}$ of distilled water orally via gastric gavage. Group II: received GTE in a dose of 150 $\mathrm{mg} / \mathrm{kg}$ body weight dissolved in $3 \mathrm{ml}$ distilled water) orally via an orogastric tube. Group III: took NAC dissolved in warm distilled water in a dose of $150 \mathrm{mg} / \mathrm{kg}$ daily orally through orogastric intubation. Group IV: received nicotine S.C. injection in a dose of $0.4 \mathrm{mg} / 100 \mathrm{gm}$ body weight/day. Group V: received S.C nicotine in a dose of $0.4 \mathrm{mg} / 100 \mathrm{gm}$ body weight/day with concomitant administration of aqueous GTE (NT + GTE). Group VI: received S.C. nicotine in a dose of $0.4 \mathrm{mg} / 100 \mathrm{gm}$ body weight/day with concomitant administration of NAC (NT + NAC). After 28 days, the animals were sacrificed and blood samples were obtained. RAPD analysis was done and markers of oxidative stress as Malondialdehyde (MDA), total antioxidant capacity (TAOC) and reduced glutathione (GSH) were also assessed. Results: Biochemical assays showed a significant decrease in serum GSH, total antioxidant capacity in the nicotine-treated group than both protected group. On contrary, a significant increase in serum MDA was recorded in the nicotine-treated group than protected groups. RAPD analysis in the nicotine-treated rats revealed evident profile changes, while no change in DNA banding pattern was detected if simultaneous administration of either GTE or NAC together with nicotine. Conclusion: These results suggest that nicotine induces oxidative stress in rats as well as a genotoxic effect; these effects could be prevented by the administration of either NAC or GTE.
\end{abstract}

KEYWORDS: Nicotine; genotoxicity; oxidative stress; NAC; Green tea; RAPD. 


\section{INTRODUCTION}

Tobacco smoking is considered a global threat, according to the Global Burden of Disease (GBD) reports; more than one in ten deaths worldwide is attributed to smoking in 2015. The negative impacts of smoking were represented in early deaths, growing disease burden, and disabilities which in turn were reflected on loss in productivity with an increase in health care expenditure. The generated estimates of smoking incidence with its negative hazards show a sizeable decline in developed countries, but future fatality in lower-income countries is expected to be huge. (GBD 2015)

Genotoxins, substances inducing DNA structure alterations (deletions, insertions, inversions, rearrangements, and recombination). Nicotine is accused of having carcinogenic potential; in 1990 , it was stated to induce chromosomal aberrations. In 2004, a significant increase was found in micronuclei frequency in gingival fibroblasts of human beings. Recent studies in humans have depicted dosedependent DNA damage after shortterm nicotine exposure in lymphatic tissue, testicular tissue, embryonic cells, as well as salivary gland cells. (Arabi,

\section{4; Kleinsasser et al., 2005; Demirhan et al., 2011)}

Various techniques and strategies were applied to detect DNA damage and mutations including polymerase chain reaction (PCR), comet assay, radioimmunoassay (RIA) and chemiluminescence strategies as enzyme-linked immunosorbent assay (ELISA) and immune-histochemical assay. (Svetlova et al., 2009; Figueroa-González\& PérezPlasencia, 2017) However, Random amplified polymorphic DNA (RAPD) yields patterns of DNA fragments, it is based upon amplification of arbitrary segments of DNA using polymerase chain reaction (PCR) with short primers of indiscriminate nucleotide sequence. The rapidity and efficiency of RAPD make it an ideal tool for genomic alteration study. (Kumari\& Thakur, 2014)

Nowadays, a great increase in interest has been paid to the protective effects of natural antioxidants (derived from plants) against substances inducing genome instability. (Costa\& Nepomuceno, 2006; Kumar et al., 2016) Green tea is one of the most popular beverages consumed worldwide. Polyphenols; the strongest constituents of green tea have been demonstrated to possess potent antioxidant, anti-mutagenic and anticarcinogenic properties. (Chengelis et al., 2008)

$\mathrm{N}$-acetylcysteine (NAC) supplementation, has received attention since it has shown clinical efficiency as antioxidant and anti-inflammatory. (Duailibi et al., 2017) NAC has the property to scavenge reactive oxygen species and restore the pool of the intracellular reduced glutathione. (Goncalves et al., 2010)

However, the effectiveness of both GTE and NAC in protection against nicotine genotoxicity has not been fully elucidated. Thus, the present study was intended specifically to investigate the probable genotoxic effect of nicotine 
and to assess the possible protective role of GTE and NAC.

\section{MATERIALS \& METHODS}

\section{- Chemicals:}

Green tea extract (GTE) was obtained from Technomed Groups Company, Egypt, "in the form of tablets (200 mg)". The tablets were dissolved in distilled water.

$\mathbf{N}$-acetyl-L-cysteine was purchased from Sigma-Aldrich Chemical Company in the form of powder (purity of $99 \%$ ). Solutions of NAC were made daily prior to dosing by dissolving NAC in warm distilled water, Lot\#WXBC0011V $\mathrm{V}^{\text {PCode:1002158587. }}$

Nicotine in the form of a solution (Formula: C10H14N2) was supplied from Sigma-Aldrich Chemical Company (Germany) Lot\#SZBE245XV.

\section{- Experimental design:}

The study included thirty healthy adult male Wister albino rats, weighing 150-200g. All procedures were in accordance with the rules of the animal care and handling and the study protocol was approved by the ethical committee of Alexandria Faculty of Medicine. The rats were randomly assigned to 6 groups (6 rats each) as follows:

Group I: Rats received $3 \mathrm{ml}$ of distilled water orally via an orogastrictube.

Group II: Rats received GTE "150 $\mathrm{mg} / \mathrm{kg}$ body weight dissolved in $3 \mathrm{ml}$ distilled water, orally via an orogastrictube". (Hamdy et al. 2012)
Group III: Rats received NAC dissolved in warm distilled water in a dose of $150 \mathrm{mg} / \mathrm{kg}$ daily orally through orogastric intubation. (Sudheer et al., 2008)

Group IV: Rats received a subcutaneous injection of nicotine $(0.4 \mathrm{mg} / 100 \mathrm{gm}$ body weight). This selected dose is equivalent to the amount of nicotine passing to the blood of the heavy smoker. (Aydos et al., 2001)

Group V: rats received nicotine in the same dose as group IV, concomitant with the previously adjusted dose of GTE.

Group VI: rats received nicotine in the same dose as group IV, concomitant with the previously adjusted dose of NAC.

After 28 days, the animals were sacrificed, and blood samples were obtained.

- DNA damage assessment:

\section{- Chemicals for DNA extraction:}

GFX genomic DNA purification kit from whole blood (purchased from Amersham Biosciences UK Ltd). The following components are included (Red blood cell lysis solution, extraction solution, wash solution, GFX columns and collection tubes).

- Chemicals for DNA amplification:

- $2 X$ PCR Master Mix

- Primers : Table 1 (Singh \& Roy, 2001) 
Table (1): Selected primers for Random Amplified Polymorphic DNA.

\begin{tabular}{|c|c|}
\hline Primers & Sequence $\mathbf{5}^{\mathbf{}} \mathbf{- 3}$ \\
\hline ' \\
\hline Primer 1 & CCGGCTACGG \\
\hline Primer 2 & CAGGCCCTTC \\
\hline Primer 3 & TACGGACACG \\
\hline Primer 5 & AGCTTCAGGG \\
\hline Primer 6 & AGGCATTCCC \\
\hline Primer 7 & GGTCTGAACC \\
\hline Primer 8 & ACGGTACACG \\
\hline Primer 9 & GTCCTCAACG \\
\hline Primer 10 & CTTCACCCGA \\
\hline
\end{tabular}

- Agarose (1.5\% Agarose for routine use).

- TBE Buffer, 10 X Ready-Mixed Powder MB grade.

- Ethidium Bromide.

- DNA Ladder as a molecular weight marker consisting of 13 fragments ranging in sizes from $100 \mathrm{bp}$ to $1000 \mathrm{bp}$.

\section{Methods:}

\section{- DNA damage assessment:}

\section{Sample collection:}

Two venous blood samples were collected from each rat $(2 \mathrm{ml})$ at the start of the study and after 28 days.

These samples were collected in EDTA tubes and kept at $2-8^{\circ} \mathrm{C}$ up to one day for DNA extraction.

\section{DNA extraction:}

DNA extraction was done using GFX genomic DNA Purification Kit from EDTA whole blood sampling. The purified DNA was stored at $-20^{\circ} \mathrm{C}$ till the time of analysis in sterile Eppendorf tubes $1.5 \mathrm{ml}$ containing phosphate buffer saline.

\section{Quantitative measurement of DNA:}

To adjust the concentration of DNA in the reaction by spectrophotometric technique, the extracted DNA from each sample was determined by NanoDrop spectrophotometer at $260 \mathrm{~nm}$ wavelength for measurement of nucleic acid concentration and the sample purity was determined by the ratio of nucleic acid /protein absorbances $=\left(\mathrm{A}_{260} / \mathrm{A}_{280}\right)$. Samples were accepted when the $260 / 280$ ratio $\geq 1.8$, then the concentration of DNA was adjusted to $100 \mathrm{ng}$ and optimized for all samples in order to exclude variability in DNA concentrations. (Atienzar \& Jha, 2006).

\section{DNA amplification (Random Amplified Polymorphic DNA) (Papadopoulos et al., 2002)}

Using the PCR technique with 10 selected arbitrary primers.

PCR was conducted using QB PCR Thermocycler. PCR reaction mixture and programs were optimized.

\section{Reaction mixture:}

$100 \mathrm{ng}$ of genomic DNA was amplified in a total volume of $50 \mu \mathrm{L}$ consisting of:

- $25 \mathrm{ml}$ master mix solution

- $1 \mathrm{ml}$ of each primer (total is 10 $\mathrm{ml}$ primers)

- Adjusted DNA concentration (X $\mathrm{ml}$ purified DNA) and distilled water were added up to $50 \mathrm{ml}$.

\section{PCR program:}

The thermocycler was turned on and programmed as follows:

Heated lid at $105^{\circ} \mathrm{C}$, thirty-five cycles of denaturation (at $94{ }^{\circ} \mathrm{C}$ for 30 
seconds), annealing (at $37^{\circ} \mathrm{C}$ for $1 \mathrm{~min}$ ), and extension (at $72^{\circ} \mathrm{C}$ for 2 min) were performed.

\section{DNA detection procedures:}

Submarine gel electrophoresis was used and visualization of the amplified bands by UV transilluminator, for detection of DNA lesions.

After viewing the gel, it was photographed with a gel documentation system with Dolphin software.

\section{- Assay of oxidative status}

\section{Antioxidant enzymes and lipid peroxidation}

Blood samples were collected (no anticoagulant was used) for determination of markers of oxidative stress. The blood was allowed to clot for 30 minutes at $25^{\circ} \mathrm{C}$, and then centrifuged at $4000 \mathrm{rpm}$ for 15 minutes at $4^{\circ} \mathrm{C}$. The top yellow serum layer was separated using pipette without making a disturbance to the white buffy layer.

- Assessment of total antioxidant capacity (TAOC)

The assay was determined according to Koracevic et al., (2001). TAOC measurement is based on the appearance of a colored product when hydrogen peroxide is added. The values were expressed as $\mathrm{mM} / \mathrm{L}$.

\section{- Reduced glutathione}

Reduced glutathione (GSH) content was measured using the method of Miwa et al., (1989). The principle of this method is the reduction of $5,5^{\prime}$ dithio-bis (2-nitro benzoic acid)
(DTNB) by sulfhydryl of GSH producing a yellow product. The values were expressed as $\mathrm{mg} / \mathrm{dl}$.

\section{- Malondialdehyde}

Malondialdehyde (MDA) was estimated by the method described by Ohkawa et al., (1979) using thiobarbituric acid (TBA). MDA was measured by reading the absorbance at $532 \mathrm{~nm}$ and the values were expressed as $\mathrm{nmol} / \mathrm{ml}$.

\section{- Statistical analysis}

All analyses were conducted using SPSS software (Version 20). The differences of the mean values of the oxidative stress parameters among the six studied groups were tested using Ftest (ANOVA) as the data were normally distributed. The comparison between every two groups was analyzed using and Post Hoc test (Tukey). A P-value less than 0.001 was considered statistically significant.

\section{RESULTS}

\section{Biochemical Results (Table 2):}

- Regarding mean levels of oxidative stress markers, there were no statistically significant differences between the three control groups. While there was a statistically significant difference between the nicotine-treated group and any control group whether negative control receiving distilled water or positive control receiving GTE or NAC.

- There was also a statistically significant difference between the nicotine-treated group and either of 
both protected group regarding mean levels of MDA and GSH, while mean TAOC level although being higher in both protected groups than that in the nicotinetreated group but the difference wasn't statistically significant.

- There were no statistically significant differences between both protected groups regarding the measured three oxidative stress parameters, denoting that they have nearly the same effect on restoring the antioxidant capacity.

- No statistically significant differences were detected between either of two protected groups and the negative control group regarding the three oxidative stress markers.

Table (2): Comparison between the studied groups according to different markers of oxidative stress.

\begin{tabular}{lccc}
\hline & $\begin{array}{c}\text { MDA } \\
(\mathbf{n m o l} / \mathbf{m l})\end{array}$ & $\begin{array}{c}\text { GSH } \\
(\mathbf{m g} / \mathbf{d l})\end{array}$ & $\begin{array}{c}\text { TAOC } \\
(\mathbf{m M} / \mathbf{L})\end{array}$ \\
\hline $\begin{array}{l}\text { Group I } \\
\text { (Ho) }\end{array}$ & $4.8^{\mathrm{ac}} \pm 0.5$ & $2.1^{\mathrm{a}} \pm 0.4$ & $1.6^{\mathrm{ac}} \pm 0.4$ \\
$\begin{array}{l}\text { Group II } \\
\text { (GTE) }\end{array}$ & $4.3^{\mathrm{a}} \pm 0.6$ & $2.3^{\mathrm{a}} \pm 0.4$ & $2.0^{\mathrm{a}} \pm 0.4$ \\
$\begin{array}{l}\text { Group III } \\
\text { (NAC) }\end{array}$ & $4.4^{\mathrm{a}} \pm 0.6$ & $2.2^{\mathrm{a}} \pm 0.4$ & $1.8^{\mathrm{a}} \pm 0.4$ \\
$\begin{array}{l}\text { Group IV } \\
\text { Nicotine } \\
\text { treated group }\end{array}$ & $8.1^{\mathrm{b}} \pm 0.9$ & $1.1^{\mathrm{b}} \pm 0.2$ & $0.7^{\mathrm{b}} \pm 0.2$ \\
$\begin{array}{l}\text { Group V } \\
\text { Protected } \\
\text { group (GTE) }\end{array}$ & $6.1^{\mathrm{c}} \pm 0.7$ & $1.8^{\mathrm{a}} \pm 0.3$ & $1.1^{\mathrm{bc}} \pm 0.1$ \\
$\begin{array}{l}\text { Group VI } \\
\text { Protected } \\
\text { group (NAC) }\end{array}$ & $6.0^{\mathrm{c}} \pm 0.6$ & $2.0^{\mathrm{a}} \pm 0.4$ & $1.2^{\mathrm{bc}} \pm 0.2$ \\
\hline $\begin{array}{l}\text { F } \\
\text { p }\end{array}$ & $23.419^{*}$ & $8.897^{*}$ & $13.816^{*}$ \\
\hline & $<0.001^{*}$ & $<0.001^{*}$ & $<0.001^{*}$ \\
\hline
\end{tabular}

- F: F for ANOVA test, pairwise comparison between every 2 groups was done using Post Hoc Test (Tukey) 0.05

- *: Statistically significant at $\mathrm{p} \leq$

- Means with Common letters are not significant (i.e. Means with Different letters are significant)

\section{RAPD Results:}

DNA pattern of the second samples was studied in comparison with DNA of their control samples for each rat included in the study.

\section{Group I, II, III: (control groups)}

No detectable DNA damage in the second samples was recorded on either GT or NAC administration. Neither GT nor NAC treatment produces any genotoxic effects to the normal lymphocytes.

\section{Group IV: (Nicotine treated group)}

All rats exposed to nicotine had an indication of DNA damage in the second samples, which was reflected in the modification of their RAPD patterns if compared to their control profile. These changes took the form of variation or modifications in band intensity or size, loss of bands (missing bands) and new bands gain. Fig.1-3 


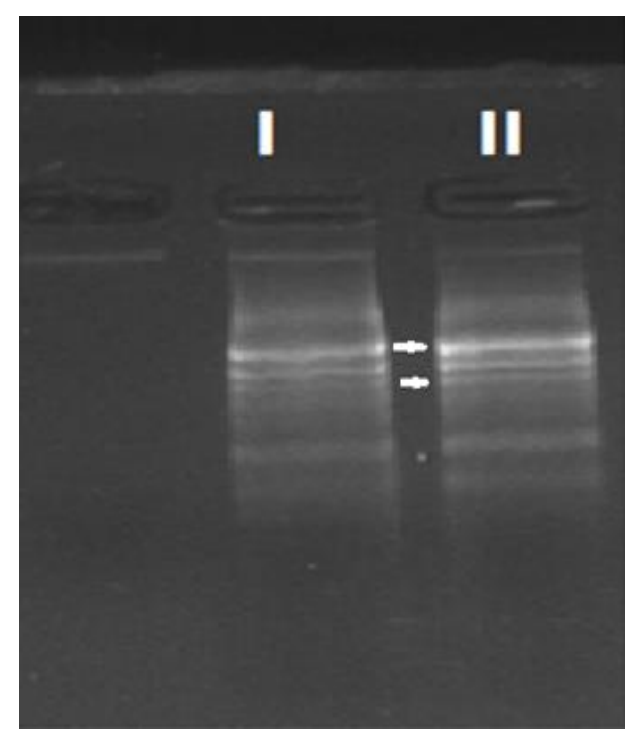

Figure (1): Photograph of DNA electrophoretic pattern of blood samples from a rat receiving nicotine for four weeks, using RAPD analysis, showing changes in DNA profiles before and after exposure. Arrows on the gel show some obvious modifications in RAPD profiles.

Lane 1: Control sample

Lane 2: Second sample showing $\uparrow$ band intensity and band gain

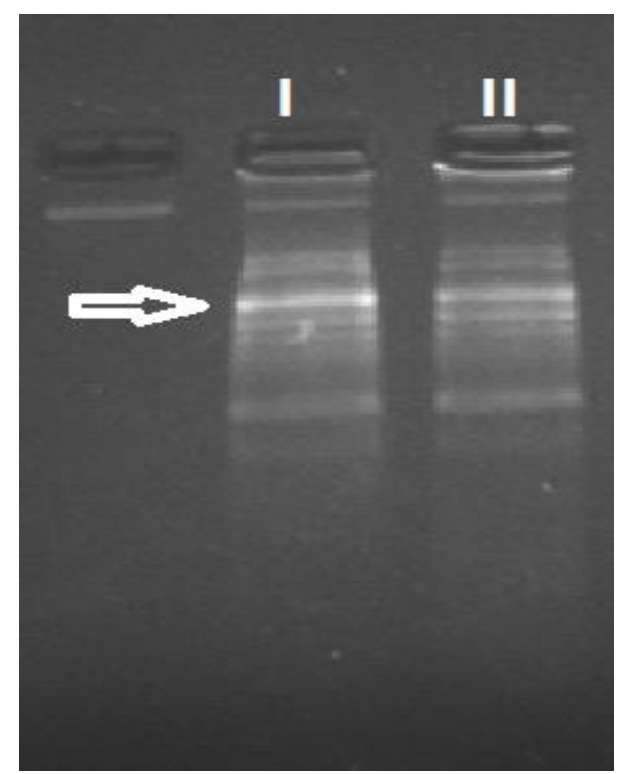

Figure (2): Photograph of DNA electrophoretic pattern of blood samples from a rat receiving nicotine for four weeks, using RAPD analysis, showing changes in DNA profiles before and after exposure.

Lane 1: Control sample

Lane 2: Second sample showing $\downarrow$ band intensity

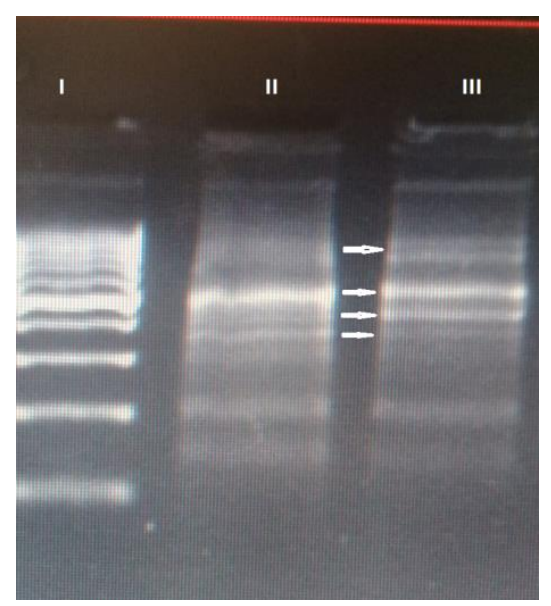

Figure (3): Photograph of DNA electrophoretic pattern of blood samples from a rat receiving nicotine for four weeks, using RAPD analysis, showing changes in DNA profiles before and after exposure. 
Lane 1: Molecular weight marker (DNA ladder)

\section{Lane 2: Control sample}

Lane 3: Second sample showing all DNA

band

$$
\text { changes (two bands gain, } \downarrow
$$$$
\text { intensity, } \uparrow \text { band intensity, }
$$

and

$$
\text { band loss) }
$$

The main change following nicotine treatment was the difference in band intensities followed by band loss then band gain. $60 \%$ of the nicotinetreated rats showed more than one type of DNA change.

\section{Group V, VI: (Protected groups)}

Simultaneous administration of GTE or NAC with nicotine protects the lymphocytes from nicotine-induced toxicity, giving the same banding pattern (profile) after exposure similar to that before exposure. Fig. 4 demonstrates that the banding profiles for the protected groups remained unchanged.

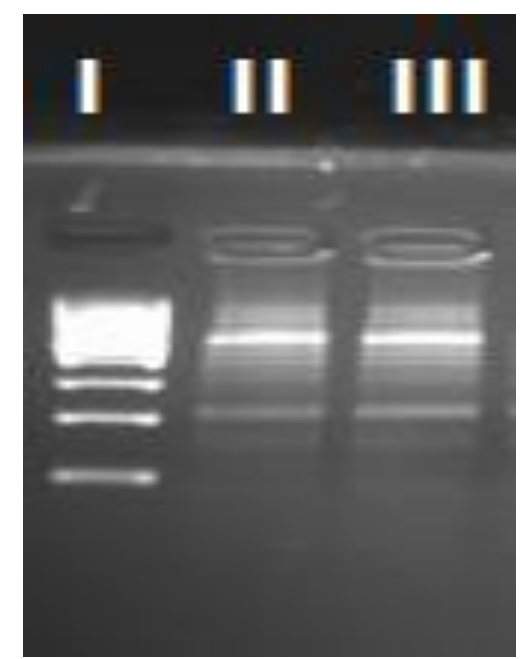

First case (NT + GTE)

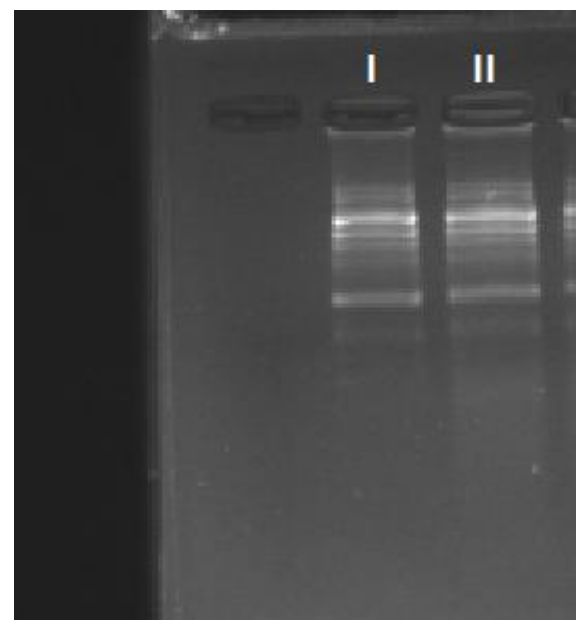

Second case $(\mathrm{NT}+\mathrm{NAC})$

Figure (4): Photograph of DNA electrophoretic pattern of blood samples from a rat receiving nicotine for four weeks together with green tea in the first case and the other from a rat receiving $\mathrm{NAC}$ in the second case, using RAPD analysis, showing no change in DNA profiles before and after exposure.

- The first case (NT + GTE)

Lane 1: Molecular weight marker (DNA ladder)

Lane 2: Control sample 
showing no

Lane 3: Second sample

change in DNA

profile

- The second case (NT + NAC)

Lane 1: Control sample

Lane 2: Second sample showing no change in DNA profile

\section{DISCUSSION}

With the aim of elucidating the probable genotoxic effect of nicotine, as well the possible protective effect of GTE and NAC, the duration of the study (4 weeks), was selected on the basis that nicotine provokes genotoxicity following long-term exposure, according to Ginzkey et al. (2014). However, Bandyopadhyaya et al. (2008) demonstrated DNA changes after 21 days of subcutaneous nicotine tartrate injection in female rats.

In the current study, there were changes detected in DNA patterns in the nicotine-treated group in the form of variation or modifications in band intensity or size, loss of bands (missing bands) and bands gain. In concordance, many studies revealed the genotoxic effect of nicotine on different tissues. (Arabi, 2004; Argentin \& Cicchetti, 2004; Kleinsasser et al., 2005; Demirhan et al., 2011)

Genomic rearrangement or point mutations cause alterations in oligonucleotide templates resulting in occurrence of band loss. Nelson et al. (1996) hypothesized that either DNA damage in the primer binding sites or the formation of DNA photoproducts could negatively affect the PCR reaction (blocking or reducing the polymerization of DNA).

Genotoxic substance induces DNA modifications, hindering the binding of the selected primer causing band disappearance. While, the appearance of new bands as well as an increase in bands intensity, could be attributed to the fact that following structural changes, more priming sites were accessible to oligonucleotide primers. (Pietrasanata et al., 2000; Enan, 2006)

As suggested by Atienzar et al. (1999), genomic template instability controlled by the degree of DNA damage and the effectiveness of DNA repair and replication could result in new annealing events, hence the appearance of a novel band (band gain). Furthermore, if large deletion occurs, this may approximate annealing sites together causing an increase in band intensity.

Kumari \& Thakur (2014) stated that change in band intensity could reflect the efficiency of amplification of particular regions with a direct relationship between numbers of copies and band intensity.

Despite that the precise mechanism underlying nicotine genotoxicity is still obscure; the induction of reactive oxygen species and free radicals is proved to play an important role in the occurrence of nicotine toxicity including genotoxicity. (Argentin \& Cicchetti, 2006)

Reactive oxygen species (ROS) induce cytotoxic and nucleic acid damage and DNA bands breakage. 
(Hemnani \& Parihar, 1998) This is consistent with Sudheer et al., (2007a) as they reported in vitro blood lymphocyte DNA damage provoked by nicotine, through lipid peroxidation.

In the present work, the level of serum GSH and the total antioxidant capacity were declined in the nicotinetreated group, with a significant increase in serum MDA levels in the nicotine-treated group if compared to the other groups. This is consistent with the results declared by Dey et al (2010) and Mosbah et al., (2015).

MDA is a recognized biomarker of oxidative stress. It is one of the main oxidation products of peroxidized polyunsaturated fatty acids. Lipid peroxidation was hypothesized as an important mechanism of nicotineinduced toxicity. (Del Rio et al., 2005; Mahapatra et al., 2009)

Many lipid peroxidation products causing DNA damage especially MDA which is the most mutagenic product causing DNA adduct and alters gene expression (Esterbauer et al., 1990; Eder et al., 2006).

The lack of genotoxic effect of GTE in the current study is consistent with previous literature. (Isbrucker et al., 2006a; Fujii et al., 2008; Ogura et al., 2008) Moreover, its genoprotective effect has been widely reported against many mutagens as aflatoxin B1 (Ito et al., 1989), benzo[a]pyrene (Sasaki et al., 1993), mitomycin C (Han, 1997), UV (Wei et al., 1999), tobacco-specific nitrosamine (Chung, 1999)

In the present study, simultaneous administration of GTE or NAC with nicotine protects the lymphocytes from nicotine-induced genotoxicity. This was demonstrated by unchanged banding profiles of the protected groups. Moreover, no statistically significant differences were detected between either of two protected groups and the negative control group regarding the three measured oxidative stress markers, denoting the efficacy of NAC and GTE in restoring the antioxidant capacity. This agrees with Sudheer et al., (2007a) and Mosbah et al., (2015).

Concurrent administration of GTE with nicotine offers significant protection of the genomic material in addition to amelioration of the biochemical markers of oxidative stress as green tea polyphenols are potent antioxidants. The same result obtained in a human trial of Han et al. (2011) that revealed a significant decline in oxidation-related DNA damage after GTE administration for 28 days. Pandurangan et al (2012) reported that GTE protected against genotoxicity and lipid peroxidation induced by 4nitroquinoline 1-oxide in Wistar rats.

GTE is known to increase the amount of anti-oxidative enzymes in the blood and function as antioxidants to scavenge ROS through the generation of stable phenolic radicals. (Forester \& Lambert, 2011) Polyphenols chelate redox-active metal ions ( $\mathrm{Fe}$ and $\mathrm{Cu}$ ), thus hindering the formation of metal-catalyzed free radicals. Moreover, Sinha et al., (2007) reported that GTE stimulates DNA repair which has been verified by the high expression of DNA repair enzymes.

$\mathrm{N}$-acetylcysteine has different protective mechanisms against DNA damage and carcinogenesis as a result 
of its nucleophilicity, antioxidant activity, modulation of metabolism and detoxification, effects on mitochondria and modulation of DNA repair, in addition to regulation of cell survival and apoptosis. (Mansour et al., 2008)

NAC feeding to nicotine-treated rats caused protection against oxidative stress (replenished GSH, decreased MDA), and maintain the genetic structure. Campain, (2004) reported that nicotine caused both less oxidative damage and fewer micronuclei formation in the cells pretreated with NAC confirming that NAC had a very efficient protective role against toxicity caused by nicotine through replenishing GSH stores and scavenging the free radicals formed.

The causative relationship between ROS and nicotine-induced DNA damage is illustrated by many previous research findings involving pretreatment with antioxidants like NAC, ellagic acid or ferulic acid, where nicotine resulted in a lesser production of ROS or micronuclei with restoring the normality to nearly all comet parameters. (Argentin \& Cicchetti, 2004; Sudheer et al., 2007 a; Sudheer et al., 2008)

\section{CONCLUSION}

In conclusion, the research findings illustrated evidence of DNA damage induced by nicotine exposure which was revealed as changes in rats RAPD profiles in the form of bands loss or gain, and variations in bands intensity. The study revealed that RAPD analysis has been an efficient biomarker assay for the detection of the genotoxic effects of nicotine. Moreover, the benefit of simultaneous intake of either
NAC or green tea as modifiers of nicotine-induced genotoxicity and oxidative stress state was also verified.

\section{RECOMMENDATIONS}

As appearance or loss of bands in DNA profile gives limited information, a more informative analysis could be obtained after cloning and sequencing of these polymorphic RAPD bands. It is also recommended a daily intake of green tea and NAC either in food or in beverages for protection against nicotine-induced diseases and reduction of cancer risk in case of chronic exposure.

\section{REFERENCES}

Arabi M. (2004): Nicotinic infertility: assessing DNA and plasma membrane integrity of human spermatozoa. Andrologia 36: 305310.

Argentin G \& Cicchetti R. (2004): Genotoxic and anti-apoptotic effect of nicotine on human gingival fibroblasts. Toxicol Sci 79:75-81.

Argentin, G \& Cicchetti, R. (2006): Evidence for the role of nitric oxide in anti-apoptotic and genotoxic effect of nicotine on human gingival fibroblasts. Apoptosis 11: 1887-1897.

Atienzar FA, Cordi B, Evenden AJ. (1999): Qualitative assessment of genotoxicity using random amplified polymorphic DNA: comparison of genomic template stability with key fitness parameters in Daphnia Magna exposed to benzo [a] pyrene. Environ Toxicol Chem 18: 2275-2282. 
Atienzar FA \& Jha AN. (2006): The random amplified polymorphic DNA (RAPD) assay and related techniques applied to genotoxicity and carcinogenesis studies: A critical review. Mutat Res 613: 76102.

Aydos K, Güven MC, Can B, Ergün A. (2001): Nicotine toxicity to the ultrastructure of the testis in rats. BJU Int. 88 (6): 622- 626.

Bandyopadhyaya G, Sinha S, Chattopadhyay BD, Chakraborty A. (2008): Protective role of curcumin against nicotine-induced genotoxicity on rat liver under restricted dietary protein. Eur J Pharmacol. 588 (2-3): 151-157.

Campain, JA. (2004): Nicotine: potentially a multifunctional carcinogen? Toxicol. Sci. 79: 1-3.

Chengelis CP, Kirkpatrick JB, Regan KS, Radovsky AE, Beck MJ, Morita O. (2008): 28-Day oral (gavage) toxicity studies of green tea catechins prepared for beverages in rats. Food Chem Toxicol 46: 978-989.

Chung FL. (1999): The prevention of lung cancer induced by a tobaccospecific carcinogen in rodents by green and black tea. Proc. Soc. Exp. Biol. Med. 4: 244-248.

\section{Costa WF \& Nepomuceno JC.} (2006): Protective effects of a mixture of antioxidant vitamins and minerals on the genotoxicity of doxorubicin in somatic cells of Drosophila melanogaster. Environ Mol Mutagen. 47(1): 18-24.
Del Rio D, Stewart AJ, Pellegrini N. (2005): A review of recent studies on malondialdehyde as toxic molecule and biological marker of oxidative stress. Nutr Metab Cardiovasc Dis. 15(4): 316-328.

Demirhan 01, Demir C, Tunç E, nandıklığlu N, Sütcü E, Sadıkoğlu N, Ozcan B. (2011): The genotoxic effect of nicotine on chromosomes of human fetal cells: the first report described as an important study. Inhal Toxicol. 23(13): 829-834.

Dey SK \& Roy S. (2010): Role of reduced glutathione in the amelioration of nicotine-induced oxidative stress. Bull Environ Contam Toxicol. 84(4):385-389.

Duailibi MS, Cordeiro Q, Brietzke E, Ribeiro M, LaRowe S, Berk M, Trevizol AP. (2017): Nacetylcysteine in the treatment of craving in substance use disorders: systematic review and metaanalysis. Am J Addict. 26: 660666.

Eder E, Wacker M, Lutz U, Nair J, Fang X, Bartsch H, et al. (2006): Oxidative stress-related DNA adducts in the liver of female rats fed with sunflower-, rapeseed-, olive- or coconut oil supplemented diets. Chem Biol Interact. 159(2): 81-89.

Enan MR. (2006): Application of random amplified polymorphic DNA (RAPD) to detect the genotoxic effect of heavy metals. Biotechnol Appl Biochem 43:147154. 
Esterbauer H, Eckl P, Ortner A. (1990): Possible mutagens derived from lipids and lipid precursors. Mutation Research 238 (3): 223233.

Figueroa-González G \& PérezPlasencia C. (2017): Strategies for the evaluation of DNA damage and repair mechanisms in cancer. Oncol Lett. 13(6): 3982-3988.

Forester SC \& Lambert JD. (2011): Antioxidant effects of green tea. Mol Nutr Food Res. 55(6): 844854.

Fujii H, Nishioka H, Wakame K, Magnuson BA, Roberts A. (2008): Acute, subchronic and genotoxicity studies conducted with Oligonol, an oligomerized polyphenol formulated from lychee and green tea extracts. Food Chem. Toxicol. 46 (12), 3553-3562

Ginzkey C, Steussloff G, Koehler C, Hackenberg S, Richter E, Hagen R, et al. (2014): Nicotine causes genotoxic damage but is not metabolized during long-term exposure of human nasal miniorgan cultures. Toxicol Lett. 229 (1): 303310 .

Goncalves JF, Fiorenza AM, Spanevello RM, Mazzanti CM, Bochi GV, Antes FG, et al. (2010): N-Acetylcysteine prevents memory deficits, the decrease in acetylcholinesterase activity and oxidative stress in rats exposed to cadmium. Chem.Biol. Int. 186: 5360.

Hamdy MA, El-Maraghy SA, Kortam MA. (2012): Modulatory effects of curcumin and green tea extract against experimentally induced pulmonary fibrosis: a comparison with $\mathrm{N}$-acetyl cysteine. J Biochem Mol Toxicol. 26 (11): 461-468.

Han C. (1997): Screening of anticarcinogenic ingredients in tea polyphenols. Cancer Lett. 114 153158.

Han KC, Wong WC, Benzie IFF. (2011): Genoprotective effects of green tea (Camellia Sinensis) in human subjects: results of a controlled supplementation trial. $\mathrm{Br}$ J Nutr 1: 1-8.

Hemnani T \& Parihar MS. (1998): Reactive oxygen species and oxidative DNA damage. Indian $\mathbf{J}$ Physiol Pharmacol. 42(4): 440-452.

Isbrucker RA, Bausch J, Edwards JA, Wolz E. (2006a): Safety studies on epigallocatechin gallate (EGCG) preparations. Part 1: genotoxicity. Food Chem. Toxicol. $44 \quad$ (5): 626-635. http://dx.doi.org/10.1016/j.fct.2005. 07.005 .

Ito Y, Ohnishi S, Fujie K. (1989): Chromosome aberrations induced by aflatoxin $\mathrm{B} 1$ in rat bone marrow cells in vivo and their suppression by green tea. Mutat. Res. 222: 253261.

Kleinsasser NH, Sassen AW, Semmler MP, Harréus UA, Licht AK, Richter E. (2005): The tobacco alkaloid nicotine demonstrates genotoxicity in human tonsillar tissue and 
lymphocytes. Toxicol Sci. 86 (2): 309-317.

Koracevic D, Koracevic G, Djordjevic V, et al. (2001): Method for the measurement of antioxidant activity in human fluids. J Clin Pathol 54(5): 356361.

Kumar M, Lalit M, Thakur R. (2016): Natural antioxidants against arsenic-induced genotoxicity. Biol Trace Elem Res.170 (1): 84-93.

Kumari N \& Thakur SK. (2014): Randomly amplified polymorphic DNA-a brief review. American Journal of Animal and Veterinary Sciences 9 (1): 6-13.

Mahapatra SK, Das S, Bhattacharjee S, Gautam N, Majumdar S, Roy S. (2009): In vitro nicotine-induced oxidative stress in mice peritoneal macrophages: a dose-dependent approach. Toxicol Mech Methods 19(2): 100-108.

Mansour HH, Hafez HF, Fahmy NM, Hanafi N. (2008): Protective effect of $\mathrm{N}$-acetylcysteine against radiation-induced DNA damage and hepatic toxicity in rats. Biochemical Pharmacology 75: 773-

780. http://dx.doi.org/10.1016/j.bcp .2007.09.018

Miwa S, Luzzatto L, Rosa R, et al. (1989): Recommended methods for an additional red cell enzyme (pyrimidine5'-nucleotidase) assay and the determination of red cell adenosine 5'- triphosphate, 2,3diphosphoglycerate, and reduced glutathione. Clin Lab Haematol 11:131-136.

Mosbah R, Yousef MI, Mantovani A. (2015): Nicotine-induced reproductive toxicity, oxidative damage, histological changes, and haematotoxicity in male rats: The protective effects of green tea extract. Exp Toxicol Pathol. 67(3): 253-259.

DOI: 10.1016/j.etp.2015.01.001.

Nelson JR, Lawerence CW, Hinkle DC. (1996): Thymine-thymine dimmer bypass by yeast DNApolymerase-zeta. Science 272: 1646-1649.

Ogura R, Ikeda N, Yuki K, Morita O, Saigo K, Blackstock C, et al. (2008): Genotoxicity studies on green tea catechin. Food Chem. Toxicol. 46 (6): 2190-2200. http://dx.doi.org/10.1016/j.fct.2008. 02.016 .

Ohkawa H, Ohishi N, Yagi K. (1979): Assay for lipid peroxides in animal tissues by thiobarbituric acid reaction. Anal Biochem 95(2): 351358.

Pandurangan AK, Periasamy S, Anandasadagopan SK, Ganapasam S, Srinivasalu SD. (2012): Green tea polyphenol protection against 4-nitroquinoline 1-oxide-induced bone marrow lipid peroxidation and genotoxicity in Wistar rats. Asian Pac J Cancer Prev. 13 (8): 4107-4112.

Papadopoulos S, Benter T, Anastassiou G, Pape M, Gerhard S, Bornfeld N, et al. (2002): Assessment of genomic instability 
in breast cancer and uveal melanoma by random amplified polymorphic DNA analysis. Int $\mathbf{J}$ Cancer 99: 193-200.

\section{Pietrasanata LI, Smith BL, MacLeod} MC. (2000): A novel approach for analyzing the structure of DNA modified by benzo[a]pyrine diol epoxide at single-molecule resolution. Chem Res Toxicol 13: 351-355.

Sasaki YF, Yamada H, Shimoi K, Kator K, Kinae N. (1993): The clastogen-suppressing effects of green tea, Po-lei tea and rooibos tea in $\mathrm{CHO}$ cells and mice. Mutat. Res. 286: 221-232.

Singh KP \& Roy D. (2001): Identification of novel breast tumor-specific mutation(s) in the q11.2 region of chromosome 17 by RAPD/AP-PCR fingerprinting. Gene 269: 33-43.

\section{Sinha D, Dey S, Bhattacharya RK,} Roy M. (2007): In vitro mitigation of arsenic toxicity by tea polyphenols in human lymphocytes. J Environ Pathol Toxicol Oncol 26: 207-220.
Sudheer AR, Muthukumaran S, Devipriya N, Devaraj H, Menon VP. (2008): Influence of ferulic acid on nicotine-induced lipid peroxidation, DNA damage and inflammation in experimental rats as compared to $\mathrm{N}$-acetylcysteine. Toxicology 243: 317-329.

Sudheer, A.R., Muthukumaran, S., Devipriya, N., Menon, V.P. (2007a): Ellagic acid, a natural polyphenol protects rat peripheral blood lymphocytes against nicotine-induced cellular and DNA damage in vitro: with the comparison of $\mathrm{N}$-acetylcysteine. Toxicology 230: 11-21.

\section{Svetlova MP, Solovjeva LV, Tomilin}

NV. (2009): Chapter 6. Application of new methods for detection of DNA damage and repair. Int Rev Cell Mol Biol. 277: 217-251. DOI: 10.1016/S1937-6448(09)77006-6.

Wei H, Zhang X, Zhao JF, Wang JY, Bickers D, Lebwohl M. (1999): Scavenging of hydrogen peroxide and inhibition of ultraviolet lightinduced oxidative DNA damage by aqueous extracts of green and black teas. Free Radic. Biol. Med. 26:1427-1435. 


\section{الملخص العربيى}

تقييم الدور الوقائي لمستخلص الثاي الأخضر الأسيتيل سيستايين-ن ضد التسمم الجينى المحتمل

$$
\begin{aligned}
& \text { للنيكوتين في ذكور الفئران البيضاء البالغة }
\end{aligned}
$$

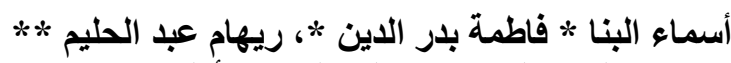

$$
\begin{aligned}
& \text { قسم الطب الثرعي * الباثولوجيا الأكلينيكية } \\
& \text { كلية الطب- جامعة الإسكندرية }
\end{aligned}
$$

مقدمة: النيكوتين نفسه لا يصنف على أنه مادة مسرطنة ، ولكن هنالك أدلة متز ايدة على أنه قد يكون لديه إمكانات سمية جينية كانت نقطة اهتمام للبحث لأثر.

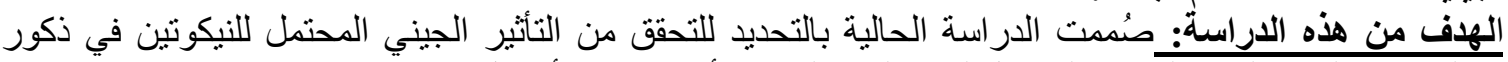

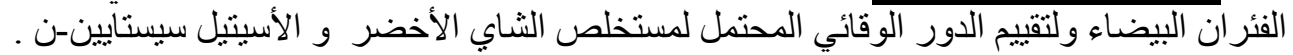

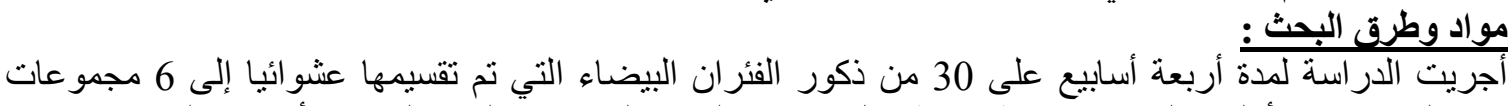

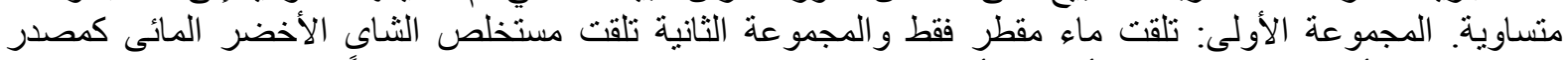

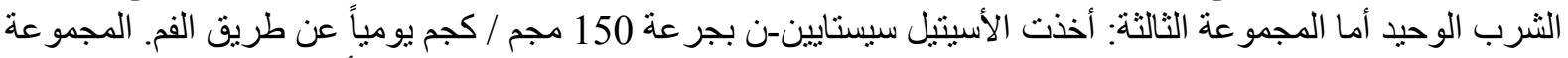

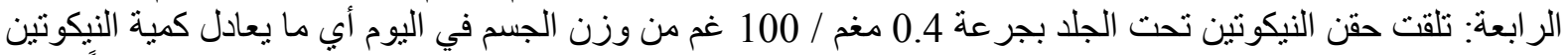

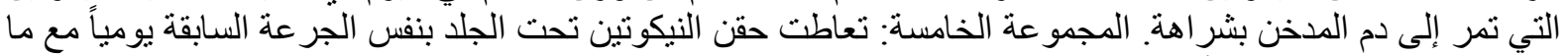

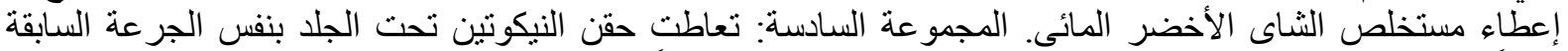

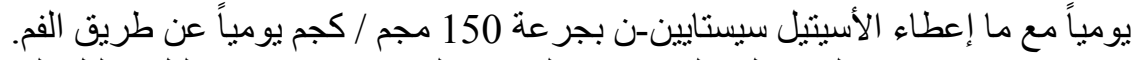

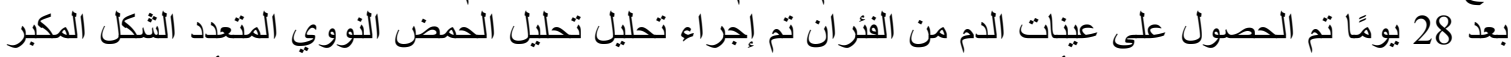

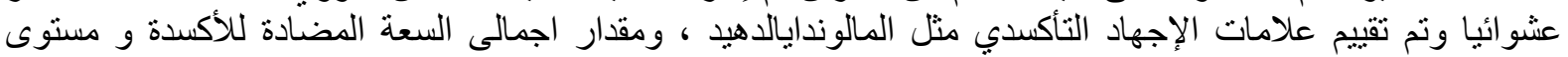

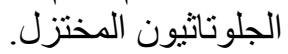

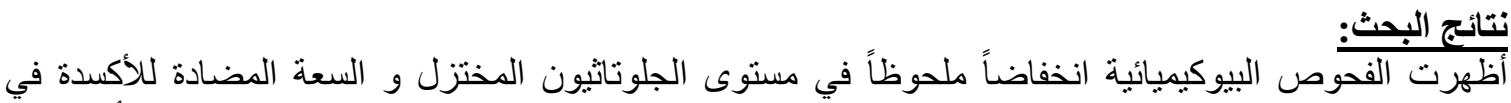

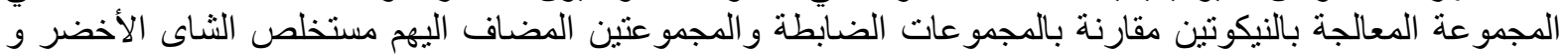

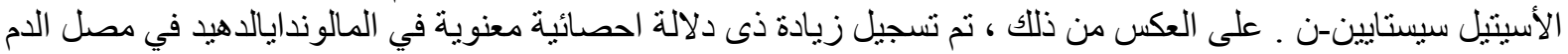

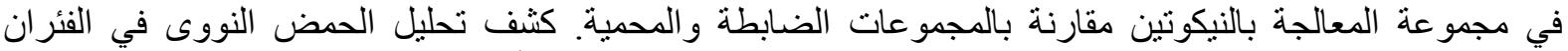

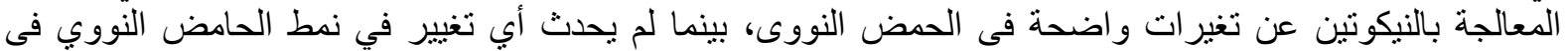
المجمو عتين المضاف اليهم مستخلص الثناى الأخضر و الأسيتيل سيستايين-ن .

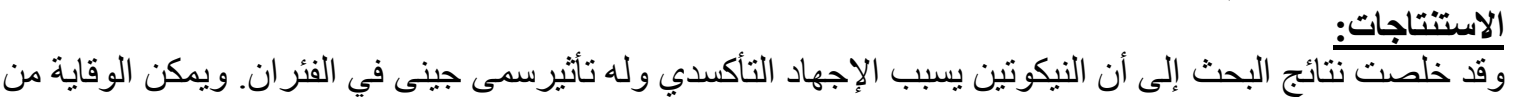

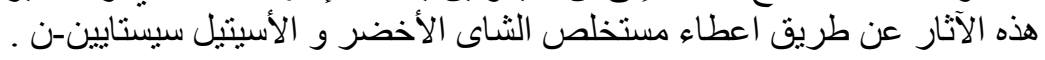

